\title{
EFFECT OF QUIZIZZ TOWARDS THE ELEVENTH-GRADE ENGLISH STUDENTS' READING COMPREHENSION IN MOBILE LEARNING CONTEXT
}

\author{
N.W.I. Priyanti ${ }^{1}$, M.H. Santosa ${ }^{2}$, K.S. Dewi ${ }^{3}$ \\ English Language Education \\ Universitas Pendidikan Ganesha \\ Singaraja, Indonesia \\ e-mail: wayan.ita.priyanti@undiksha.ac.id,mhsantosa@undiksha.ac.id, sintyadewi@undiksha.ac.id
}

\begin{abstract}
Abstrak
Penelitian ini bertujuan untuk mengetahui pengaruh aplikasi Quizizz bagi siswa kelas sebelas dalam pembelajaran bahasa inggris. Jenis penelitian yang digunakan yaitu kuasi-eksperimental dengan desain post-test only control group desain. Populasi penelitian adalah seluruh kelas sebelas SMA Negeri 4 Singaraja tahun 2018/2019 berjumlah 370 siswa. Sampel penelitian berjumlah 37 siswa sebagai kelompok eksperimen yang di beri perlakuan melalui aplikasi Quizizz dan 36 siswa sebagai kelompok kontrol yang diberi perlakuan melalui pembelajaran konvensional. Metode pengumpulan data dalam menggunakan tes pilihan ganda. Berdasarkan hasil data, diperoleh nilai kelompok eksperimen $(M=83.08$, $p$ value $=0.018)$ dan nilai kelompok kontrol $(M=80.77$, $p$ value $=0.018)$. Hal ini menunjukan bahwa nilai rata-rata kelompok eksperimen lebih besar dari kelompok control dan nilai signifikan menunjukan $p$ value $0.018<0.05$. Hasil tersebut juga di dukung oleh spesifikasi hasil test yang menunjukan bahwa pengaruh Quizziz mendominasi aspek literal recognition. Dapat disimpulkan bahwa pembelajaran mobile menggunakan aplikasi Quizizz berpengaruh terhadap pemahaman membaca siswa.
\end{abstract}

Kata kunci: Quizizz, mobile learning, pemahaman membaca

\section{Abstract}

The research's aim was to investigate the effect of Quizizz towards the eleventh grade students' English study. A quasi-experimental utilizing a post-test only control group was employed for data gathering. Research's population included eleventh-grade students in SMA Negeri 4 Singaraja. The sample was 37 students of XI IPS 1 as the experimental group who were treated through Quizizz and 36 students of XI IPS 2 as the control group who were treated through conventional teaching strategy. The method of data collection employed multiple choice test. The result showed scores of experimental group $(M=83.08, p$ value $=0.018)$ and control group $(M=80.77, p$ value $=0.018)$. Mean score of experimental group was higher than the control group $(83.08>80.77)$ and the $p$ value was 0.018 or less than 0.05. The small effect was supported by result specification of reading comprehension text dominated by literal recognition aspects. In conclusion, Quizizz affected students reading comprehension.

Keywords: Quizizz, mobile learning, reading comprehension

\section{INTRODUCTION}

The speed of technological innovation emerges quickly as a trend in the $21^{\text {st }}$ century. The wave of change is extremely noticed through the information that can be accessed every time and everywhere by many people all over the world. Unconsciously, the use of technology automatically shifts the daily routine of the post-millennial generation in term of lifestyle, social interaction, economic and education (Sarica and Cavus 2009).

Santosa (2017) argues that generation $Z$ rise as the digital user that lives in the world of a digital stage. It means that generation $Z$ was born as technological users. One of the noticeable characteristics of generation $Z$ is the term social networking when everything is 
already on their hand through a web, internet, Smartphone, laptops, freely available network, and digital media (Sigh and Dangmei 2016). As the generation who could not live without the existence of technology, the learning process should be integrated into the use of technology itself.

English as a global language provides access and connection for every aspect of human to have a good future career in the digital era. It cannot be denied that Revolution 4.0 is coming because most of the people already using technology as their daily need. The existence of technology itself should be integrated into the learning process that purposed to make the students have the knowledge to face the Forth Industrial Revolution. However, the fact is most of the students especially in Indonesia is still struggling in mastering the English language as their foreign language. It is mostly caused by books and the teacher are only the main source that to support English language learning of the students.

Integrating innovative media and technology need to be implemented in the school. Based on the preliminary observation conducted by the researcher in a senior high school in North Bali Indonesia, one of the problems faced by the students in learning English is in term of reading. This situation becomes the challenge and problem faced by the students in English learning are specified in reading comprehension (Yadav and Zhou 2017).

In line with the assumption of the teachers, the preliminary observation about the learning style of the students, it is found that the students are allowed to bring a mobile phone (Smartphone) to the classroom. On the other hand, since the use of mobile technology is allowed in school, it brings a problem that most of the students do not use their mobile in a proper way Therefore, the result of the report from UNESCO notes that reading in the mobile era shares strategies to effective mobile usage in facilitating the language learning where literacy includes reading rates are low.

Reading as a major focus on the educational field becomes the heart of all formal learning skill. The success or failure of the students in reading skill resonates throughout the rest of their life in the future. Reading also enables students to acquire the information, knowledge, and skill that they need in life. The quality of reading skill has a strong impact on English language ability. The more students have skill in reading, the more they will be opened up with a new world, increase the vocabulary, language development, and familiar with a variety of writing style.

In Indonesia, reading comprehension is stated in Permendikbud No. 59 Tahun 2014. It also has a close relationship with the Curriculum 2013 that has been implemented in most of the Indonesian school. The content in Permendikbud No. 59 Tahun 2014 presents three main aspects to be competent and capable of reading. The first is the comprehension of social function which refers to the function of the text in the social context or in real life. The second is the comprehension of text structure which focuses on how the information within a written text is organized. The last is the comprehension of the language feature which meant as the features of language that support meaning

With the technological advances, learning has been utilizing mobile applications to support learning activities. This strategy is called as Mobile-Assisted Language Learning (MALL). MALL is a strategy that emerges to build a new look of language learning. Most of the teachers in several places already tried to integrate these changes and utilize Smartphone into their classes by using MALL strategy (Kilicakaya and Krajka 2010). In general, the main characteristic of MALL strategy is the notion of mobility. This notion refers to the language learner brand new learning experience where language learning especially knowledge about vocabulary can take place anywhere. This characteristic offers many benefits for language learners and it can be implemented in senior high school level (Sharples, et al. 2009).

Modern pedagogical paradigm and trends get reinforced by the use of ICT. It creates a new approach and technique to engage the activeness of the students in learning. Then, one of the trends to become the solution to this current situation is throughout gamification. Gamification refers to the use of game-based mechanism and game thinking to engage students, motivate action, promote learning, and solve problems (Kapp 2012). In a simple 
way, gamification is the use of approach and element as game thinking which different context from the games is. There are some software tools for gamification, such as Kahoot!, Quizizz, FlipQuiz, Duolingo, Ribbon Hero, ClassDojo, and many more. Those are suitable to see the automatic progress and result of the students in the learning process. Here, Quizizz as the focus of the current research will be one of the tools that will be employed.

According to Vygotsky's Zone of Proximal Development (ZPD) which has a closer relationship with the idea of scaffolding states that ZPD guides the students to represent the skill level outside the students' comfort and mastery. However, scaffolding refers to the instructional support in learning such as quizzes, games, instructions, tutoring, that facilitate learning within the students' ZPD. Regarding that case, a quiz can be the one that can scaffold the process of language learning in the classroom since the quiz and game can be the instructional support (Vygotsky 1962). Quizizz as a digital platform to assists the students' mastery in reading is a fun multiplayer classroom activity that allows all students to practice reading skill together by using their mobile phones like a tablet, Ipad, or even Smartphone (Mei, Ju and Adam 2018).

Numerous research related to the Mobile-Assisted Language Learning (MALL) have been conducted for supporting this current research. The first is international research using Quizizz.com to enhance pre-intermediate students' vocabulary knowledge by Icin and Orta (2018). The aim of this research is to investigate the relationship between mobile assisted language learning and vocabulary learning integrated with Quizizz platform. As a result, it indicates that mobile assisted language learning may be effective in teaching and learning vocabulary. Then, the research by Mei, Ju, and Adam (2018) about implementing Quizizz as game-based learning in Arabic classroom conducted research to evaluate the platform of Quizizz in Arabic class. Results show a high total number of percentages toward using Quizizz game during the Arabic class and it affects the students to be more interesting and more focus on learning English. Those researches are already implemented Quizizz in engaging vocabulary mastery.

Based on the consideration above, the researcher decided to investigate the significant effect of using Mobile-Assisted Language Learning (MALL) integrated with Quizizz towards Reading Comprehension of the eleventh-grade senior high school students at SMA Negeri 4 Singaraja. Regarding the observation and data analysis done in that school, Quizizz platform was already employed by an English lecturer at the English Language Education Department Undiksha in vocabulary class. As a result, it showed an enthusiastic learning situation and the students were motivated in learning vocabulary. Since vocabulary becomes the part of reading, the gap for this current research is investigating the effect of Quizizz towards reading comprehension of eleventh-grade students at SMA Negeri 4 Singaraja. The curiosity of the research about the implementation of Quizizz in reading context leads the researcher to conduct research entitled 'Effect of Quizizz towards the Eleventh Grade English Students' Reading Comprehension in Mobile Learning Context".

\section{METHOD}

A quasi-experimental research utilizing post-test only control group design was employed to check whether there is a cause-effect relationship between the variables, data, and how the data will be compared (Creswell and Clark 2011). An Experimental research design was randomly assigned to two groups. The groups could be matched based on the students that had the same background of knowledge. The normality of both classes was needed to do a parametric test which purposed to prove that the classes are in the normal distribution (Pallant 2010). The result of the normality test showed that the value of sig. in KolmogorovSmirnov for XI IPS 1 was .081 and for XI IPS 2 was .074. Since the value of both groups was higher than 0.05 , therefore it can be assumed that both classes are in a normal distribution. After analyzing the normality and homogeneity, the groups were divided into experimental group and control group. In this case, the experimental group was taught by using of MobileAssisted Language Learning (MALL) integrated with Quizizz, while the control group was taught by using conventional teaching strategy.

Language and Education Journal Undiksha $\mid 73$ 
Table 1 Post-Test Only Control Group Design (Fraenkel and Wallen 2008)

\begin{tabular}{|c|c|c|c|}
\hline $\begin{array}{l}\text { Experimental } \\
\text { Group }\end{array}$ & $\mathrm{R}$ & $\mathrm{X}$ & O \\
\hline Control Group & $\mathrm{R}$ & $\mathrm{Y}$ & $\mathrm{O}$ \\
\hline \multirow[t]{3}{*}{$\begin{array}{l}2 \text { Classes from } \\
11 \text { are randomly } \\
\text { selected }\end{array}$} & $\begin{array}{l}\text { "R" Random } \\
\text { Class (XI IPS } \\
\text { 1) }\end{array}$ & $\begin{array}{lr}\text { X (treated using Mobile- } \\
\text { Assisted } & \text { Language } \\
\text { Learning } & \text { (MALL) }\end{array}$ & "O" Post-Test \\
\hline & & $\begin{array}{l}\text { integrated with Quizizz } \\
\text { Application) }\end{array}$ & \\
\hline & $\begin{array}{l}\text { "R" Random } \\
\text { Class (XI IPS } \\
\text { 2) }\end{array}$ & $\begin{array}{lr}\text { Y } \quad \text { treated } & \text { using } \\
\text { Conventional } & \text { Teaching } \\
\text { Strategy } & \end{array}$ & "O" Post-Test \\
\hline
\end{tabular}

The target population of this research was 370 students of the eleventh grade in SMA Negeri 4 Singaraja. There were two groups involved as samples. Sample refers to the selection from the population or the representatives of all population (Chaudhury and Banerjee 2010). This current research employed cluster random sampling technique in selecting the sample. Cluster random sampling was chosen as the sampling technique for it is impossible to select the individual samples from the population. Taherdoost (2016) stated that Cluster random sampling is chosen for the situation when the population is already divided into a group. As it is already formed as a group, he explained further that the researcher used random sampling in deciding the groups as the sample. Regarding this, cluster random sampling was conducted to take the sample. Among the two classes, XI IPS 1 and XI IPS 2 will be selected as the sample. Then, the SPSS program will be used in order to check the homogeneity and normality of the sample. After checking the homogeneity and normality of the sample, the researcher took the lottery in order to decide the treatment for the groups. Those experimental groups given treatment as Group 1 for XI IPS 1 will be taught by using Mobile-Assisted Language Learning (MALL) integrated with Quizizz. Then, group 2 for XI IPS 2 will be taught by using conventional teaching strategy.

In conducting the steps of both strategies, the groups were given the treatment six-times. The instrument used to gather the data was reading comprehension test. To valid the content validity of the instrument, the researcher helped by expert judge sheet and calculated using Gregory formula. To valid the empirical validity, the researcher employed try out test on another class and calculated using ANATEST V4. Both content validity and empirical validity were used to make sure that the instrument was valid and reliable before conducting posttest. The formula used in order to check the content validity was drawn as $C V=\frac{D}{A+B+C+D}$.

The procedure of data collection was started by deciding the participants of the research, Then, preparing the instruments of study, checking content validity using expert judges sheet, Here, the result of content validity was calculated using Gregory formula, In testing the empirical validity, the researcher conducted try out for the test in the class which was not be chosen as the experimental group. Then the result of try out test were analyzed using ANATES V4 program. After fixing the instruments, the researcher applied the treatment to the experimental group which was taught by using Mobile-assisted language learning (MALL) integrated with Quizizz. After the treatment was done, it was continued by conducting a reading comprehension test (post-test) for the experimental group and analyzing the score of the post-test descriptively and inferentially. The result was calculated and analyzed using two forms of statistical analysis, namely descriptive analysis, and inferential analysis by using SPSS program version 24.0. Then, hyphothesis testing was employed to decide the independent sample t-test. Finally, the last was summarizing the result of the research.

To find the effect of the treatments on reading comprehension, the final test was conducted at the source of data to determine the effect. finally, the data were analyzed using 
descriptive and inferential statistical analysis. In verifying the influence of independent variable to the dependent variable and to know how well the treatment works, this research employed the calculation of effect size. The calculation of effect size in independent t-test and a correlation coefficient can be derived as presented below.

$$
\begin{aligned}
& \text { Cohen's } \mathrm{d}=\frac{\mathrm{M} 1-\mathrm{M} 2}{\sqrt{S p 2}} \\
& \text { here, }\left(\mathrm{Sp}=\frac{(n 1-1) s 1^{2}+(n 2-1) s 2^{2}}{n 1+n 2-2}\right) \\
& \text { rYl } \quad=\frac{d}{\sqrt{\left(d^{2}+4\right)}}
\end{aligned}
$$

Note: $\mathrm{M}_{1}=$ Mean Score of Experimental Group, $\mathrm{M}_{2}=$ Mean Score of Control Group, $\mathrm{Sp}=$ Pooled Standard Deviation, $\mathrm{n}_{1}=\mathrm{Sum}$ of experimental group, $\mathrm{n}_{2}=$ Sum of control group, $\mathrm{s}_{1}=$ Standard deviation of experimental group, $\mathrm{s}_{2}=$ Standard deviation of control group.

After obtaining the value of Cohen's $d$, the score was matched with the following scale that is aimed to interpret the effect size. Effect size is useful because it provides an objective measure of the importance of an effect (Cohen 1988). The constitution of a large, a medium, and a small effect can be seen in Table 2.

Table 2 Effect size value

\begin{tabular}{lll}
\hline Size & $\begin{array}{l}\text { Eta squared }(r) \\
\text { (\% of variance } \\
\text { explained) }\end{array}$ & $\begin{array}{l}\text { Cohen's } \mathrm{d} \\
\text { (standard deviation } \\
\text { units) }\end{array}$ \\
\hline Small & .01 or $1 \%$ & $0.2<\mathrm{d}<0.5$ \\
\hline Medium & .06 or $6 \%$ & $0.5<\mathrm{s}<0.8$ \\
\hline Large & .138 or $13.8 \%$ & $0.8<\mathrm{d}<2.0$ \\
\hline
\end{tabular}

\section{FINDINGS AND DISCUSSION}

The validity test was done to check the validity of the instrument (reading comprehension test) before the post-test was given to the students. The result of two expert judges can be seen as follows:

Table 3 Tabulation Table of content validity

\begin{tabular}{|l|l|l|l|}
\hline & \multicolumn{3}{l}{ Judge I } \\
\hline \multirow{2}{*}{ Judge } & & Irrelevant & Relevant \\
\cline { 2 - 4 } & Irrelevant & $\mathrm{A}(2)$ & $\mathrm{B}$ \\
\cline { 2 - 4 } & Relevant & $\mathrm{C}(1)$ & $\mathrm{D}(47)$ \\
\hline
\end{tabular}

$\begin{aligned} \text { Content Validity } & \frac{47}{2+0+1+77} \\ & =\frac{47}{50}=0,94\end{aligned}$

Based on the calculation of the content validity measurement result between Judge I and Judge II in Table 3, it showed that the content validity of the test was 0.94 .

Where:

Column A: disagree between two examiners

Column B/C: the different agreement between two examiners

Column D: the agreement between two examiners

Here are the criteria for measuring content validity. 
Table 4 Criteria in measuring content validity

\begin{tabular}{lll} 
No & Criteria & Level \\
\hline 1 & $0.80-1.00$ & Very High \\
\hline 2 & $0.60-0.79$ & High \\
\hline 3 & $0.40-0.59$ & Moderate \\
\hline 4 & $0.20-0.39$ & Low \\
\hline 5 & $0.00-0.19$ & Very Low
\end{tabular}

Based in Table 4, there were five criteria in measuring content validity of the test within its level such as $0.80-1.00$ which means in a very high level, 0.60-0.79 means high level, 0.40-0.59 means moderate, 0.20-0.39 means low, and 0.00-0.19 means very low. After checking the content validity test which was employed by the expert Judges, it showed that the content validity was exceeded 0.94 . In relation to the result, 0.94 belongs to the criteria 0.80 - 1.00. Therefore, the content validity of the reading comprehension test before conducting the post-test was very high level.

Then, normality and homogeneity test were conducted. Normality test and homogeneity test were needed to do a parametric test ( (Pallant 2010). Both of the tests are the requirement to do t-test. Normality test was used to check whether the data are normally spread or not. However, homogeneity test was used to check whether the groups (experimental and control groups) were the same or not. In this current research, the sample have been qualified as homogenous and normally spread because both reading score in the previous basic competency were calculated using SPSS 24.0.

Table 5 Table Descriptive Statistics Analysis

\begin{tabular}{lccccccc}
\hline \multicolumn{2}{c}{ Descriptive statistics } & & & & & \\
& $\mathrm{N}$ & $\mathrm{Mi}$ & Max & Mean & Mode & $\begin{array}{l}\text { Varia } \\
\text { nce }\end{array}$ & Std. dev \\
\hline $\begin{array}{l}\text { Experime } \\
\text { ntal }\end{array}$ & 37 & 76 & 90.00 & 83.08 & 84 & 14.35 & 3.78 \\
\hline Control & 36 & 74 & 88.00 & 80.7 & 82 & 18.57 & 4.31 \\
\hline $\begin{array}{l}\text { Valid N } \\
\text { (list wise) }\end{array}$ & & & & & & & \\
\hline
\end{tabular}

Based on the result of data distribution in Table 5, it can be seen that there are eight statistics were presented such as mean, median, mode, standard deviation, variance, range, minimum and maximum.

Table 6 Result of independent sample t-test on post test scores

\begin{tabular}{|c|c|c|c|c|c|c|c|c|c|c|}
\hline & & \multicolumn{2}{|c|}{$\begin{array}{l}\text { Levene's } \\
\text { Test for } \\
\text { Equality of } \\
\text { Variances }\end{array}$} & \multicolumn{7}{|c|}{ t-test for Equality of Means } \\
\hline & & \multirow[t]{2}{*}{$\mathrm{F}$} & \multirow[t]{2}{*}{ Sig. } & \multirow[t]{2}{*}{$\mathrm{t}$} & \multirow[t]{2}{*}{ df } & \multirow[t]{2}{*}{$\begin{array}{l}\text { Sig. } \\
(2- \\
\text { tail } \\
\text { ed) }\end{array}$} & \multirow{2}{*}{$\begin{array}{l}\mathrm{Me} \\
\text { an } \\
\text { Diff } \\
\text { ere } \\
\text { nce }\end{array}$} & \multirow{2}{*}{$\begin{array}{l}\text { Std. } \\
\text { erro } \\
r \\
\text { diff } \\
\text { ere } \\
\text { nce }\end{array}$} & \multicolumn{2}{|c|}{$\begin{array}{l}95 \% \\
\text { Confidence } \\
\text { Interval of the } \\
\text { Difference }\end{array}$} \\
\hline & & & & & & & & & $\begin{array}{l}\text { Lowe } \\
\mathrm{r}\end{array}$ & $\begin{array}{l}\text { Uppe } \\
\mathrm{r}\end{array}$ \\
\hline \multirow[t]{2}{*}{$\begin{array}{l}\text { Post } \\
\text { test }\end{array}$} & $\begin{array}{l}\text { Equal } \\
\text { varianc } \\
\text { es } \\
\text { assume } \\
\text { d } \\
\end{array}$ & $\begin{array}{l}1.0 \\
28\end{array}$ & $\begin{array}{l}0.3 \\
14\end{array}$ & $\begin{array}{l}2.4 \\
27\end{array}$ & 71 & $\begin{array}{l}0.0 \\
18\end{array}$ & $\begin{array}{l}2.3 \\
03\end{array}$ & $\begin{array}{l}0.9 \\
491 \\
0\end{array}$ & $\begin{array}{l}0.410 \\
8\end{array}$ & $\begin{array}{l}4.195 \\
7\end{array}$ \\
\hline & $\begin{array}{l}\text { Equal } \\
\text { varianc } \\
\text { es not } \\
\text { assume } \\
\text { d }\end{array}$ & & & $\begin{array}{l}2.4 \\
23\end{array}$ & $\begin{array}{l}69 \\
.3\end{array}$ & $\begin{array}{l}0.0 \\
18\end{array}$ & $\begin{array}{l}2.3 \\
03\end{array}$ & $\begin{array}{l}0.9 \\
507 \\
9\end{array}$ & $\begin{array}{l}0.406 \\
6\end{array}$ & $\begin{array}{l}4.199 \\
9\end{array}$ \\
\hline
\end{tabular}

Independent sample test showed the homogeneity of the data and the Sig. difference between data. In Levene's statistics, the variance of group is categorized equal or homogenous whenever the significant value exceeds 0.05 . As the result of the post-test, the 
value of Sig. $F$ is 1.028 which was higher than 0.05 . Thus, it can be said that the variance of the data was homogenous.

Based in Table 6, the value of sig. (2-tailed) was 0.018 . It can be seen that the observed level of significant (sig. 2-tailed) was less than the level of standard alpha $(\alpha=$ 0.05). Therefore, the null hypothesis was rejected $\left(\mathrm{H}_{0}\right)$ and the alternative hypothesis $(\mathrm{H \alpha})$ was accepted. It means that there was a significant effect of the implementation of MobileAssisted Language Learning (MALL) integrated with Quizizz on the eleventh grade English students' reading comprehension in SMA Negeri 4 Singaraja.

In verifying the influence of independent variable to the dependent variable and to know how well the treatment works, this research employed the calculation of effect size. The calculation of effect size in independent t-test and a correlation coefficient derived as presented below:

$$
\begin{aligned}
& \text { Cohen's } \mathrm{d}=\frac{\mathrm{M} 1-\mathrm{M} 2}{\sqrt{\mathrm{Sp2}}} \text { here, }\left(\mathrm{Sp}^{2}\right. \\
& \left.=\frac{(n 1-1) s 1^{2}+(n 2-1) s 2^{2}}{n 1+n 2-2}\right) \\
& \mathrm{Sp}^{2}=\frac{(37-1) 3.79^{2}+(n 2-1) 4.31^{2}}{(37+36)-2} \\
& =\frac{516.96+647.5}{72}=1165,46 \\
& \mathrm{Sp}^{2}=16,17 \\
& \mathrm{Sp} \quad=\sqrt{16,17} \\
& \mathrm{~d}=\frac{\mathrm{M} 1-\mathrm{M} 2}{\sqrt{S p 2}} \\
& =\frac{83,08-80,7}{\sqrt{16.17}}=\frac{2,38}{4.02}=0.59 \\
& r_{Y I} \quad=\frac{d}{\sqrt{\left(d^{2}+4\right)}} \frac{0.59}{\sqrt{(0.59+4)}}=\frac{0.59}{2.1}=0.28 \\
& =4.02
\end{aligned}
$$

Based on the result of effect size calculation, the Cohen's d exceeded 0.59 and the effect size ( $\left.r_{Y I}\right)$ exceeded 0.28 . After obtaining the value of Cohen's $d$ and the effect size calculation, the score was matched with the following scale in Table 2 that was aimed to interpret the effect size. Based in Table 2, the result of calculation using Cohen's d formulation belongs to small significant because the Cohen's d acceded 0.28 with eta squared 0.01 or $1 \%$. Therefore, the significance effect of Mobile Assisted Language Learning valued small significant effect.

In the $21^{\text {st }}$ century learning when students were handheld the technology, there is a need to re-conceptualize mobile age with the new applicable design of technology and environment for learning. It absolutely purposes to match the mobility and communication in the process of learning with digital networks. In the framework of the English language, it is noticed that the English language globally connects people to compete in the industrial revolution 4.0. Regarding the rapid of science and technology in the context of schooling in industrial revolution 4.0, English teacher appears to be an agent of change who has a role towards the successfulness of the students in English learning since they can equip the students with capabilities to grow and survive within the revolution (Forum 2016).

According to Sharples, Sanchez, Milrad, and Vavoula (2006), mobile learning becomes one of the strategies that can be employed by the teacher which matches with the situation when the smartphone becomes the essential tool to live in the digital era. Reading as the part of literacy is forced to prepare the students in facing digital literacy which emerges to build an innovative reading habit. Here, Mobile learning theory including mobile assisted language learning which focuses on learning every time and everywhere can be alternative 
learning assistance to the situation in the classroom or outside the classroom. The concept of mobile assisted language learning (MALL) brings lots of advantages for the students in terms of reading because the use of a smartphone that connects to the internet assists the students to get information. Here, gamification as part of MALL also provides a fun and innovative way to build an interest in reading and guide the students to comprehend reading a text (Deterding, et al. 2011).

Related to the implementation of mobile learning through gamification using Quizizz. The finding showed that Mobile-Assisted Language Learning (MALL) integrated with Quizizz had a significant effect on students' reading comprehension. The significance effect size of its implementation was valued small significant level. The small effect size was determined that Quizizz had a small effect on reading comprehension of the students while reading English text, especially hortatory exposition text. It might be caused by other supporting strategy that was received by the students during the treatment. Other supporting strategy might be the strategy that was received in every day. The result of descriptive statistics analysis also supported that Quizizz had a better reading comprehension achievement than the students who were treated through conventional teaching strategy. The result of post-test revealed students' ability in comprehending the text. The result of the post-test showed a different mean score between the experimental group and the control group. The mean score of both groups was the key point to predict whether there was a significant difference or not. Here, the mean score of the experimental group was 83,08 while the mean score of the control group was 80,77. In short, Mobile-Assisted Language Learning (MALL) integrated with Quizizz significantly affected the students' reading comprehension.

The result of inferential statistics analysis additionally showed that there was a significant effect of Mobile-Assisted Language Learning (MALL) integrated with Quizizz towards students' reading comprehension. The result of the inferential statistics showed that the value of Sig. (2-tailed) was 0.018 . It can be seen that the observed level of significant (Sig. 2tailed) was less than the level of standard alpha $(\alpha=0.05)$. Thus, the null hypothesis was rejected $\left(\mathrm{H}_{0}\right)$ and the alternative hypothesis $\left(\mathrm{H}_{\alpha}\right)$ was accepted which indicated that MobileAssisted Language Learning (MALL) integrated with Quizizz was positively indicated as a strategy which gave the significant effect towards the eleventh grade English students' reading comprehension at SMA Negeri 4 Singaraja.

Further, the analysis of the aspect of reading comprehension that affected most by the implementation of Mobile-Assisted Language Learning (MALL) integrated with Quizizz was conducted by the researcher. The aim is to know the strongest reading comprehension aspects that suited to using Quizizz. There were five reading aspects that have been analyzed from the students' post-test result including determining the literal recognition of the text (explicit information, word meaning, and contextual reference), reorganization (classifying into class, outlining, and synthesizing), and inference (predicting outcome, main idea, implicit information, cause and effect relationship).

The result of the analysis showed that Mobile-Assisted Language Learning (MALL) integrated with Quizizz affected all of the three reading comprehension aspects including literal recognition, reorganization, and inference. The highest difference between students' correct answer percentage was found in determining the literal recognition. Here, literal recognition was an aspect of reading which purposed to find explicit information, word meaning, and contextual reference. The result of data in finding the literal recognition $1 \%$ which was higher than the two other aspects. In short, it can be said that reading aspects that suited the most by the implementation of Mobile-Assisted Language Learning (MALL) integrated with Quizizz was determining the literal recognition.

To sum up the result, this research revealed that there was a significant effect of using mobile-assisted language learning (MALL) integrated with Quizizz towards the eleventhgrade English students' reading comprehension. This statement was supported by the result of both descriptive statistics analysis and inferential analysis. Furthermore, the reading 
comprehension aspects that mostly affected by the implementation of mobile-assisted language learning (MALL) integrated with Quizizz was determining the literal recognition.

\section{CONCLUUSION}

In conclusion, generation $\mathrm{Z}$ who was born in digital are prepared to have a ten skill including mastering English language before facing revolution 4.0. Since English as a foreign language for most Indonesian students becomes struggling which leads to some difficulties in reading and comprehending English text. It truly caused by the low rate of reading habit and the existence of technology that changes their lifestyle. Integrating innovative media to assist the students reading activity emerges in the form of educational application and educational game. Mobile-assisted language learning is one of the strategies that apply educational game in the form of gamification to create fun and innovative reading activity. Regarding the current research about implementation of gamification in reading. The result descriptive and inferential statistical analysis showed that Mobile-Assisted Language Learning (MALL) integrated with Quizizz significantly affacted the eleventh grade English students' reading comprehension in SMA Negeri 4 Singaraja. The findings showed that the mean score of students who were taught using Mobile-Assisted Language Learning (MALL) integrated with Quizizz was higher than the mean score of students who were taught by using conventional strategy. Moreover, the reading aspect analysis result showed that one among the three reading comprehension aspects that mostly affected by the implementation of Mobile-Assisted Language Learning (MALL) integrated with Quizizz was determining the inference especially predicting outcomes, main idea, implicit information, cause, and effect relationship.

\section{REFERENCE}

Alderson, C, and A.H Urquhart. What is reading? In C. Alderson, \& A. H. Urquhart (Eds.), Reading in a foreign language. London \& New York: Longman, 1984.

Andrzejewska, D.C. "Mobile Assisted Language Learning." Technology and Eeducation, 2016: Page 1-10, http://www.ejournals.eu/ZG/2016/Zeszyt-6/art/8608/.

Chaudhury, S., and A. Banerjee. "Statistics without tears: Populations and samples." Industrial Psychiatry Journal, 2010: Vol.19, No.1, doi: 10.4103/0972-6748.77642, pp.60-65.

Cohen, J. Statistical Power Analysis for the Behavioral Sciences, 2nd Edition. Hillsdale, N.J: Lawrence Erlbaum, 1988.

Creswell, J.W, and Plano Clark. Designing and Conducting Mix-Method Research (2nd Ed). Thousand Oaks: CA: Sage, 2011.

Deterding, S, D Gixon, R Khaled, and L Nacke. From Game Design Elements to Gamefulness: :"Defining Gamification". Finland:ACM: Proceedings from MindTrek 11, 2011.

Forum, World Economic. The Future of Jobs : Employment, Skills and Workforce Strategy for the Fourth Industrial Revolution. London: Global Challenge Insight Report, 2016.

Fraenkel, J, and N Wallen. Design and Evaluate Research in Education . New York: McGraw-Hill Higher Education, 2008.

Gilakjani, Abbas P, and Narjes B Sabouri. "A Study of Factors Affecting EFL Learners' Reading Comprehension Skill and the Strategies for Improvement ." International Journal of English Linguistics, 2016: Vol. 6, No. 5, pp.1923-8703.

Huang, Wendy Hsin-Yuan, and Dilip Soman. Gemification of Education. Toronto: Toronto, ON M5S 3E6, 2013.

Icin, and D.O.K.B.A Orta. "Using Quizizz.Com to Enhance Pre-intermediate Students' Vocabulary Knowledge." International Journal of Language Academy, 2018: ISSN: 2342-0251, Doi: http:/dx.doi.org/10.18033/ijla.3953. P 295-303.

Kapp, K.N. The Gemification of learning Instruction: Game-based Method and Strategies for Trainning and Education. San Francisco, USA: John Willey and Sons, 2012.

Kaur, $\mathrm{H}$, and A Pandit. "Consumer Evaluation of Brand Extension: Empirical Generalization and Comparative Analysis." Journal of Empirical Generalisations in Marketing Science, 2013: pp 119, Vol 15 No. 1.

Kilicakaya, Ferit, and Jaroslaw Krajka. "Teachers' Technology Use in Vocabulary Teaching." Journal of Education and Science, 2010: page 81-87. 
Mei, Sou Yan, Sou Yan Ju, and Zalika Adam. "Implementing Quizizz as Game Based Learning in Arabic Classroom." European Journal of Social Sciences Education Research, 2018: ISSN 2312-8429 p 1-5.

Pallant, J. SPSS Survival Manual: A step by step guide to data analysis using SPSS. New York: Allen and Unwin Book Publishers, Australia, 2010.

Santosa, M.H. "Learning Approach of Indonesian EFL Gen Z Students in a Flipped Learning Context." Journal on English as a Foreign Language, 2017: Vol. 7, No. 2, p-ISSN 2088-1657.

Sarica, G.N, and Nadire Cavus. "New Trends in 21st Century English Learning." Procedia Social and Behavioral Science, 2009: p 439-445, Doi; 10.1016/j.sbpro.2009.01.079.

Sharples, Mike, I Sanchez, M Milrad, and G Vavoula. "Mobile Learning." Techology-enhanced Learning, 2006: pp. 4-10.

Sharples, Mike, I.A Sanchez, Marcelo Milrad, and G.N Vavoula. "Mobile Learning: Small Devices, Big Issues." Technology-Enhanced Learning, 2009: DOI 10.1007/978-1-4020-9827-7 14.

Sigh, A.P, and J Dangmei. "Understanding The Generation Z: The Future of Workforce." South-Asian Journal of Multidisciplinary Studies (SAJMS), 2016: pp 1-6, ISSN: 2349788:SJIF:2.246:Volume 3 Issue 3.

Silfia, E., M. Ansyar, and M. Zaim. "Students Difficulties in Comprehending the Analytical Exposition Texts at Grade XI A of Science Program in SMAN 3 Sungai Penuh." Journal English Language Teaching (ELT), 2013: Vol.1, No.1, pp.102-110.

Taherdoost, H. "Sampling Methods in Research Methodology; How to Choose a Sampling Technique for Research." International Journal of Academic Research in Management (IJARM), 2016: Vol5, No.2, pp. 18-27.

Tuckman, B.W. Conducting Educational Research Fifth Edition . New York: Harcourt: Brace Collage Publisher, 1999.

Twarong, L, and M Pereszlenyi. "Telephone-assisted language study and Ohio 